\title{
Regulation of Insulin-like Growth Factor I Gene Expression in the Human Macrophage-like Cell Line U937
}

I. Nagaoka, B. C. Trapnell, and R. G. Crystal

Pulmonary Branch, National Heart, Lung, and Blood Institute, National Institutes of Health, Bethesda, Maryland 20892

\begin{abstract}
Activated macrophages release tissue forms of insulin-like growth factor I (IGF-I), 20-25-kD products of the IGF-I gene, thus providing an extracellular growth and differentiation signal at sites of inflammation. To examine the control of IGF-I gene expression in mononuclear phagocytes, the human macrophage-like cell line U937 was evaluated at rest and after surface activation with phorbol myristate acetate (PMA) or $\mathrm{Ca}^{2+}$ ionophore. Northern analysis and RNAse protection analysis with ${ }^{32} \mathrm{P}$-labeled IGF-I-specific probes demonstrated that the IGF-I mRNA transcripts of resting U937 cells were similar in size and amount to those of resting human alveolar macrophages, mononuclear phagocytes known to express the IGF-I gene. Nuclear run-off assays demonstrated that surface activation of U937 cells increased the transcription rate of the IGF-I gene four- to fivefold, a process that was inhibited by cycloheximide, suggesting that active protein synthesis was involved in the activation pathway. Despite this, cytoplasmic IGF-I mRNA levels after surface activation declined markedly, a process blocked by a protein kinase $\mathrm{C}$ inhibitor (for PMA activation) or a calmodulin antagonist (for $\mathrm{Ca}^{2+}$ ionophore activation). Like the increased transcription of the IGF-I gene, modulation of IGF-I mRNA transcript levels required active protein synthesis; in the presence of cycloheximide constitutive IGF-I mRNA levels increased and surface activation no longer caused a decrease in transcript number. Interestingly, surface activation caused a rapid release of IGF-I, even in the presence of a protein synthesis inhibitor, suggesting that mononuclear phagocytes have a preformed, stored, releasable pool of IGF-I. Together these observations demonstrate that IGF-I gene expression is complex and probably involves control of transcription rate, cytoplasmic mRNA levels possibly mediated through protein kinase $C$, calcium influx and calmodulin, and finally, release of preformed IGF-I from a storage pool. (J. Clin. Invest. 1990. 85:448-455.) macrophage • insulin-like growth factor I $\bullet$ gene expression
\end{abstract}

\section{Introduction}

In most organs, tissue macrophages, members of the mononuclear phagocyte system of bone marrow-derived cells, are thought to play a central role in normal wound healing and pathogenic tissue fibrosis by virtue of their ability to release a variety of polypeptide mediators that serve as growth factors

Address reprint requests to Dr. Ronald G. Crystal, Pulmonary Branch, Room 6D03, Building 10, National Institutes of Health, Bethesda, MD 20892.

Received for publication 5 June 1989 and in revised form 15 September 1989.

The Journal of Clinical Investigation, Inc.

Volume 85, February 1990, 448-455 for mesenchymal cells (1-3). Among these mediators are representatives of the insulin-like growth factor I (IGF-I) ${ }^{1}$ family of molecules, polypeptides that function as a late G1 growth signal for mesenchymal cells and probably influence growth and differentiation of a variety of cell types (4-7). Recent studies have demonstrated that, whereas blood monocytes are incapable of expressing the IGF-I gene, alveolar macrophages, the pulmonary representative of the mononuclear phagocyte system, normally contain IGF-I mRNA transcripts (8). Furthermore, alveolar macrophages recovered from the lower respiratory tract of individuals with fibrotic lung disorders such as idiopathic pulmonary fibrosis and asbestosis, are spontaneously releasing functional IGF-I type molecules, suggesting that alveolar macrophage IGF-I released in the lower respiratory tract probably plays a role in the development of pulmonary fibrosis that often accompanies chronic lung inflammation (9-11).

In the context of these observations, it is apparent that modulation of expression of the IGF-I gene in mononuclear phagocytes is relevant to both normal tissue repair and the pathogenesis of tissue fibrosis. Little is known, however, about how the IGF-I gene is regulated. As presently understood, the human IGF-I gene includes five coding exons (I-V) represented over at least $45 \mathrm{~kb}$ on chromosome 12 at q22-qter (12-14). Macrophages express at least two IGF-I mRNA transcripts, IGF-IA mRNA (representing exons I-III + V) and IGF-IB mRNA (exons I-IV), similar to the transcripts observed in liver (15-17). The exact form of the macrophage IGF-I molecule is not known, but it has a molecular mass of 20-25 kD, similar to the molecular mass of tissue forms of IGF-I produced by fibroblasts and Sertoli cells $(8,18,19)$, and the approximate mass expected based on the open reading frames within IGF-IA and/or IGF-IB mRNA transcripts (15, $16,20)$. This contrasts sharply with the serum form of IGF-I, referred to as somatomedin $\mathrm{C}$, a 7.6-kD molecule coded by sequences in exons II and III, probably processed by cleavage of larger forms of IGF-I such as IGF-IA or IGF-IB $(15,16$, 20, 21).

To begin to understand the regulation of expression of this gene in mononuclear phagocytes, we have used U937, a cell line with characteristics similar to those of human macrophages originally isolated from a human histiocytic lymphoma $(22,23)$. The data suggest that IGF-I gene expression is complex, with multiple regulatory points that include transcription rate, cytoplasmic mRNA levels, and surprisingly, release of preformed IGF-I from an intracellular storage pool.

\section{Methods}

Source of cells. Fresh human alveolar macrophages were obtained as previously described (24). The cell populations consisted of $\geq 90 \%$

1. Abbreviations used in this paper: IGF-I, insulin-like growth factor I. 
macrophages and were $\geq 95 \%$ viable by trypan blue exclusion. U937, a macrophage-like cell line (CRL1593; American Type Culture Collection, Rockville, MD), was maintained in DME (Whittaker M. A. Bioproducts, Walkersville, MD) supplemented with $4 \mathrm{mM}$ L-glutamine, $50 \mathrm{U} / \mathrm{ml}$ penicillin, $50 \mu \mathrm{g} / \mathrm{ml}$ streptomycin, and $10 \%$ heat-inactivated FCS (Biofluids, Rockville, MD). Cells were subcultured every 4- $6 \mathrm{~d}$ by seeding at $10^{6}$ cells $/ \mathrm{ml}$. The viability of U937 cells was always $>90 \%$ as assessed by trypan blue exclusion.

Evaluation of IGF-I mRNA transcripts. Expression of IGF-I mRNA transcripts in U937 cells and alveolar macrophages was compared using Northern analysis and solution hybridization/RNAse protection analyses. Cellular RNA was extracted by the guanidine isothiocyanate method (25) and poly- $\mathrm{A}^{+}$RNA was obtained by oligo-dT cellulose column chromatography. Northern blots of RNA were evaluated with an IGF-I-specific cDNA probe encompassing exons I, II, and III (pPB107, Fig. $1 A$ ) labeled by the random primer method (26). RNAse protection analysis was performed using an antisense ${ }^{32} \mathrm{P}$-labeled IGF-I cRNA derived from pPB107 $(8,27)$.

Quantification of IGF-I transcription rate. IGF-I gene transcription rate was determined by transcription run-off assay $(28,29)$. U937 cells were washed twice in PBS without calcium and magnesium (Mediatech, Herndon, VA), resuspended in serum-free DME, and then incubated $\left(6 \mathrm{~h}, 37^{\circ} \mathrm{C}\right)$ at $10^{6}$ cells $/ \mathrm{ml}\left(2.5 \times 10^{7}\right.$ cells total $)$ in 150 -mm tissue culture dishes (Falcon Plastics, Cockeysville, MD) alone or with $80 \mathrm{nM}$ phorbol 12-myristate 13-acetate (PMA; Sigma Chemical Co., St. Louis, MO) or $5 \mu \mathrm{M}$ calcium ionophore A23187 (Sigma Chemical Co.) in the presence or absence of $10 \mu \mathrm{g} / \mathrm{ml}$ actinomycin D or $10 \mu \mathrm{g} / \mathrm{ml}$ cycloheximide. The cells were then pelleted $(200 \mathrm{~g}, 5 \mathrm{~min})$ and washed twice with ice-cold PBS, and nuclei were isolated and labeled with [32P]UTP (800 Ci/mmol; Amersham Corp., Arlington Heights, IL) $(28,29)$. Transcription of the IGF-I gene and, as controls, c-fos and c- $m y c$ genes was quantitated by hybridizing $\left(40 \mathrm{~h}, 42^{\circ} \mathrm{C}\right)$ the ${ }^{32} \mathrm{P}$-labeled nuclear RNA to the specific filter-bound, unlabeled cDNA targets in the presence of $50 \%$ formamide and $10 \%$ dextran sulfate at $10^{7}$ cpm ${ }^{32} \mathrm{P}$-labeled RNA/ml. Filters were then washed and subjected to autoradiography, and the resulting autoradiograms were scanned.
IGF-I mRNA levels after surface activation. U937 cells were incubated at $37^{\circ} \mathrm{C}$ for up to $12 \mathrm{~h}$ alone or with PMA or A23187 at various concentrations $(0-20 \mu \mathrm{M}$ each). After incubation the cells were washed and total cellular RNA was isolated as described above. Cellular IGF-I mRNA levels were quantified using a solution hybridization/RNAse protection assay $(8,27)$. The ${ }^{32} \mathrm{P}$-labeled IGF-I-specific antisense cRNA probe ( 380 nucleotides) was hybridized with $10 \mu \mathrm{g}$ total cellular RNA or synthetic unlabeled IGF-I sense RNA, and subjected to RNAse treatment, purification, electrophoresis, and autoradiography (8). A standard curve of IGF-I sense RNA was constructed using various quantities of cold sense cRNA transcripts and the autoradiographic signals were quantified by a laser densitometer (2202 Ultrascan; Pharmacia LKB, Piscataway, NJ). As a further control, $\gamma$-actin mRNA transcript size and levels were evaluated by Northern analysis using a ${ }^{32} \mathrm{P}$-labeled human $\gamma$-actin cDNA probe (pHF $\left.\gamma \mathrm{A}-1\right)(30)$.

To evaluate the relative cellular compartmentalization of IGF-I transcripts in resting and surface-stimulated cells, U937 cells were

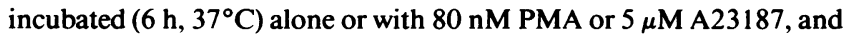
nuclear and cytoplasmic fractions were isolated by the method of Baumbach et al. (31). Nuclear and cytoplasmic RNA was then purified and IGF-I mRNA levels were quantified as described above.

Pathways involved in modulating IGF-I mRNA levels. U937 cells were incubated $\left(6 \mathrm{~h}, 37^{\circ} \mathrm{C}\right)$ with $80 \mathrm{nM}$ PMA or $5 \mu \mathrm{M} \mathrm{A23187}$ in the presence or absence of $100 \mu \mathrm{M} \mathrm{H-7}$ (1-[5-isoquinolinyl-sulfonyl]2methylpiperazine; Sigma Chemical Co.), a protein kinase $\mathrm{C}$ inhibitor or $25 \mu \mathrm{M} \mathrm{W}-7$ ( $N$-[6-aminohexyl]-5-chloro-1-naphthalene-sulfonamide; Aldrich Chemical Co., Milwaukee, WI), a calmodulin antagonist, or with various PMA analogues $\left(12 \mathrm{~h}, 37^{\circ} \mathrm{C}\right.$; all $\left.1 \mu \mathrm{M}\right)$, including phorbol, phorbol 12,13-diacetate, $4 \alpha$-phorbol 12,13-didecanoate, and phorbol 12-myristate 13-acetate-4-O-methyl ester (all from Sigma Chemical Co.). Incubations were also done at $37^{\circ} \mathrm{C}$ for various times in the presence or absence of $10 \mu \mathrm{g} / \mathrm{ml}$ actinomycin D or $10 \mu \mathrm{g} / \mathrm{ml} \mathrm{cyclo-}$ heximide. After each incubation total cellular RNA was isolated and IGF-I and $\gamma$-actin mRNA levels were quantified as described above.

Release of IGF-I after surface activation. U937 cells were incubated at $37^{\circ} \mathrm{C}$ up to $12 \mathrm{~h}$ alone or with $80 \mathrm{nM}$ PMA or $5 \mu \mathrm{M} \mathrm{A23187.} \mathrm{After}$

A

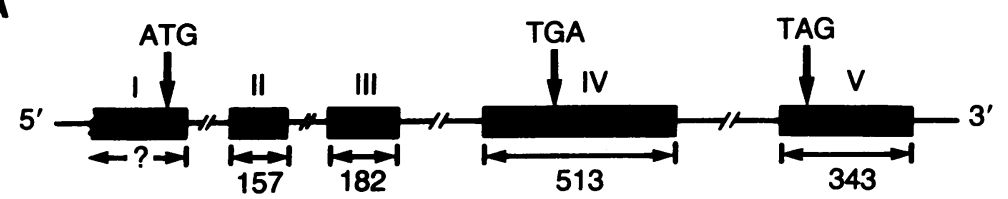

I-II-III probe

(380 nt)

B

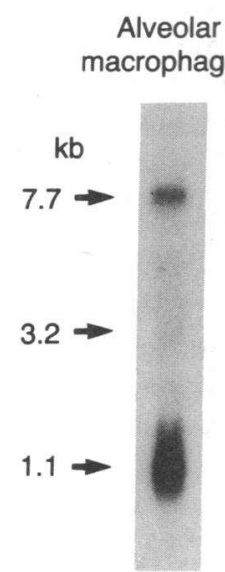

1

\section{U937} cells

C

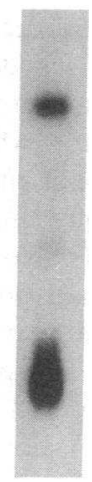

2
$0.1 \mathrm{~kb}$

-

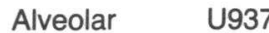
macrophages cells

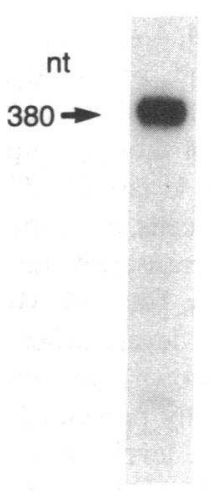

3
Figure 1. Expression of IGF-I gene mRNA transcripts in human mononuclear phagocytes. $A$, Schematic representation of the human IGF-I gene. The human IGF-I gene has five coding exons, but the complete structure of the $5^{\prime}$ portion of exon I (and/or the existence of additional $5^{\prime}$ exons) is unknown. The putative start codon (ATG) is in exon I. There are two in-phase stop codons (TGA in exon IV, TAG in exon V). Exon lengths are shown in base pairs below each exon. The probe used to evaluate IGF-I mRNA transcripts consisted of 380 nucleotides ( $n t)$ spanning exons I, II, and III. $B$, Northern analysis of IGF-I mRNA transcripts in alveolar macrophages and U937 cells evaluated with a ${ }^{32}$ P-labeled exon I-II-III IGF-I cDNA probe. Lane 1 , Poly-A ${ }^{+}$RNA $(10 \mu \mathrm{g})$ from alveolar macrophages. Lane 2 , Poly-A ${ }^{+}$RNA (10 $\left.\mu \mathrm{g}\right)$ from U937 cells. $C$, Evaluation of IGF-I mRNA transcripts in total cellular RNA from alveolar macrophages and U937 cells by RNAse protection analysis using a ${ }^{32} \mathrm{P}$-labeled IGF-I antisense cRNA probe. Lane 3, Alveolar macrophage RNA (10 $\mu \mathrm{g})$. Lane 4, U937 cell RNA (10 $\mu \mathrm{g}) .{ }^{32} \mathrm{P}$-Labeled $\phi \mathrm{X} 174 \mathrm{RF}$ DNA Hae III fragments were used as markers. 
incubation, supernatants were collected and clarified $(2,000 \mathrm{~g}, 10 \mathrm{~min})$ and the amount of IGF-I released into the media was quantified by RIA using an IGF-I-specific polyclonal antibody (Nichols Institute Diagnostics, San Juan Capistrano, CA). Quantitation of IGF-I was calibrated with highly purified recombinant IGF-I (Amgen Biologicals, Thousand Oaks, CA). The rate of IGF-I release was calculated from the amount of IGF-I released at each time point and the time interval, and expressed as picograms IGF-I released $/ 10^{7}$ cells per $15 \mathrm{~min}$. In some experiments the cellular IGF-I pool was quantified in resting U937 cells using cell sonicates. To demonstrate that U937 cell IGF-I was not associated with IGF-I binding proteins, supernatants from both resting and surface-stimulated U937 cells or cell sonicates were acidified $(0.1$ $\mathrm{M}$ glycine- $\mathrm{HCl}, \mathrm{pH} 3.6,24 \mathrm{~h}, 37^{\circ} \mathrm{C}$ ), neutralized, and assayed by RIA $(4,5,32)$. Normal human serum was used as a positive control.

To determine if IGF-I release was dependent on de novo protein synthesis, U937 cells were incubated exactly as above except with 10 $\mu \mathrm{g} / \mathrm{ml}$ cycloheximide. At various times the amount of IGF-I in the culture media was quantified by RIA. To ensure that protein synthesis was actually inhibited, parallel cultures were incubated in leucine-free DME (Biofluids) containing [ $\left.{ }^{14} \mathrm{C}\right]$ leucine $(2.5 \mu \mathrm{Ci} / \mathrm{ml} ; 337 \mathrm{mCi} / \mathrm{mmol}$; Amersham Corp.) and TCA (10\%). Insoluble radioactivity (cells + supernatant) was determined.

Statistical evaluation. All values were represented as the mean \pm SEM from three separate experiments unless otherwise noted. Paired data were evaluated using the two-tailed $t$ test.

\section{Results}

IGF-I mRNA transcripts in resting U937 cells. Northern analysis demonstrated that resting U937 cells express multiple IGF-I mRNA transcripts (a major band at 1.1-1.4 kb, and minor transcripts of 3.2 and $7.7 \mathrm{~kb}$ ) similar to those observed in human alveolar macrophages (Fig. $1 B$ ). Although multiple IGF-I transcripts were detected by Northern analysis, RNAse protection analysis of U937 cell total RNA demonstrated a single mRNA species identical to that found in alveolar macrophages (Fig. $1 C$ ). Poly-A ${ }^{+}$RNA gave similar results (not shown). IGF-I mRNA quantification demonstrated that U937 cells had $0.167 \pm 0.060 \mathrm{pg}$ IGF-I mRNA/ $\mu \mathrm{g}$ total cellular RNA, similar to that of alveolar macrophages $(0.227 \pm 0.070 \mathrm{pg}$ IGF-I mRNA/ $\mu$ g total cellular RNA, $P>0.5$ ).

IGF-I gene transcription in U937 cells. Evaluation of IGF-I gene transcription by nuclear run-off demonstrated that resting U937 cells transcribed the IGF-I gene (Fig. 2). When the cells were activated with PMA, a protein kinase C-activating agent (33), or $\mathrm{A} 23187, \mathrm{a} \mathrm{Ca}^{2+}$ mobilizing agent, the rate of

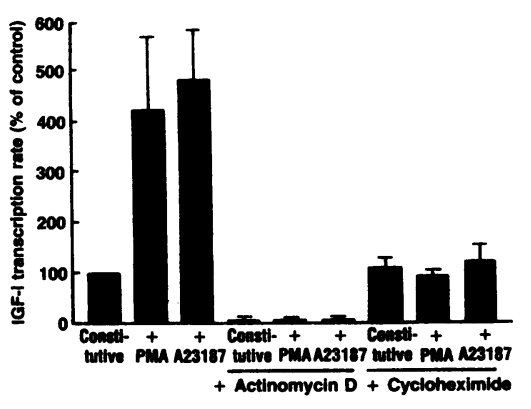

Figure 2. Rate of IGF-I gene transcription in U937 cells. The cells were incubated $(6 \mathrm{~h}$, $37^{\circ} \mathrm{C}$ ) with or without stimuli (PMA [80 nM] or $\mathrm{A} 23187[5 \mu \mathrm{M}])$ in the presence or absence of actinomycin $\mathrm{D}(10$ $\mu \mathrm{g} / \mathrm{ml})$ or cycloheximide $(10 \mu \mathrm{g} / \mathrm{ml})$. Nuclei were then isolated and

${ }^{32}$ P-labeled nuclear RNA was hybridized to excess $(5 \mu \mathrm{g})$ linearized, nitrocellulose-bound, IGF-I plasmid cDNA. The relative rate of IGF-I transcription was expressed as a percentage of that measured in nuclei from cells incubated under identical conditions except without stimuli, actinomycin D, or cycloheximide.
IGF-I gene transcription was markedly increased, from 400 to $500 \%$. In contrast, compared with resting cells PMA stimulation increased c-fos oncogene transcription by $305 \pm 57 \%$, whereas c-myc oncogene transcription was decreased by $52 \pm 3 \%$, as noted by others (29). As expected, actinomycin D, an inhibitor of RNA transcription, completely suppressed the transcription of the IGF-I gene in both resting and stimulated cells. Interestingly, cycloheximide, a protein synthesis inhibitor, did not affect constitutive IGF-I gene transcription. However, cycloheximide completely suppressed the PMA- or A23187-induced increase in IGF-I gene transcription, suggesting that active protein synthesis is necessary for these surface stimuli to upregulate the IGF-I gene.

Effect of PMA- or A23187 stimulation on IGF-I $m R N A$ levels. In contrast to the effect of PMA and A23187 on IGF-I gene transcription, both agents caused a marked time- and dose-dependent reduction in the steady-state IGF-I mRNA levels in U937 cells (Fig. 3). The amount of PMA necessary to reduce the IGF-I mRNA levels to $50 \%$ of that of the resting levels after $6 \mathrm{~h}$ stimulation was $\sim 80 \mathrm{nM}$, while $5 \mu \mathrm{M}$ A23187 was required to achieve a similar reduction. When the effect of the combination of PMA and A23187 was studied, 1 nM PMA $+2 \mu \mathrm{M}$ A23187, concentrations which had little effect on IGF-I mRNA levels by themselves, decreased the IGF-I mRNA level remarkably to $5 \%$ of the level in resting cells (Fig. $3 D$ ). While IGF-I mRNA levels were decreased by PMA and A23187, the levels of $\gamma$-actin mRNA transcripts were not changed over the dose ranges evaluated (Fig. 3, $C$ and $D$ ). Furthermore, evaluation of $18 \mathrm{~S}$ and $28 \mathrm{~S}$ ribosomal RNA on formaldehyde-agarose gels demonstrated that both remained intact after stimulation with PMA or A23187 (not shown), confirming that the decrease in IGF-I mRNA level was not due to the nonspecific degradation of cellular RNA after stimulation. Interestingly, evaluation of the nuclear and cytoplasmic fractions of U937 cells demonstrated that the effect of PMA and A23187 on IGF-I mRNA levels was different in the two compartments (Fig. 4). When cells were stimulated with PMA or A23187, the cytoplasmic IGF-I mRNA level decreased and followed the pattern observed with total cellular IGF-I mRNA (Fig. 3). In contrast, the nuclear IGF-I mRNA levels increased two- to threefold with both surface stimulants, consistent with the increased IGF-I transcription in stimulated cells (Fig. 2).

To evaluate the concept that the effect of PMA on reduction of IGF-I mRNA levels was mediated through activation of protein kinase C, IGF-I mRNA levels were quantified after incubation of U937 cells with biologically inactive PMA analogues which lack the ability to activate protein kinase C (34). Phorbol, $4 \alpha$-phorbol 12,13-didecanoate, phorbol 12,13-diacetate, and 4-O-methyl PMA had no effect on IGF-I mRNA levels after $12 \mathrm{~h}$ incubation even at the high concentration of 1 $\mu \mathrm{M}$ (not shown). Importantly, while $\mathbf{H}-7$ (a potent inhibitor of protein kinase $C$ [35]) did not affect the IGF-I mRNA level of resting cells, it completely prevented PMA-induced decrease in IGF-I transcript number (Table I). Omission of the divalent cations, $\mathrm{Ca}^{2+}$ or $\mathrm{Mg}^{2+}$, had no significant effect on IGF-I mRNA levels either in resting or PMA-stimulated U937 cells (not shown). In contrast, omission of $\mathrm{Ca}^{2+}$ (but not $\mathrm{Mg}^{2+}$ ) markedly prevented the A23187-induced reduction in IGF-I mRNA levels (not shown), demonstrating that the effect of A23187 on decreasing IGF-I transcript number was dependent on calcium influx. Consistent with the concept that this effect 

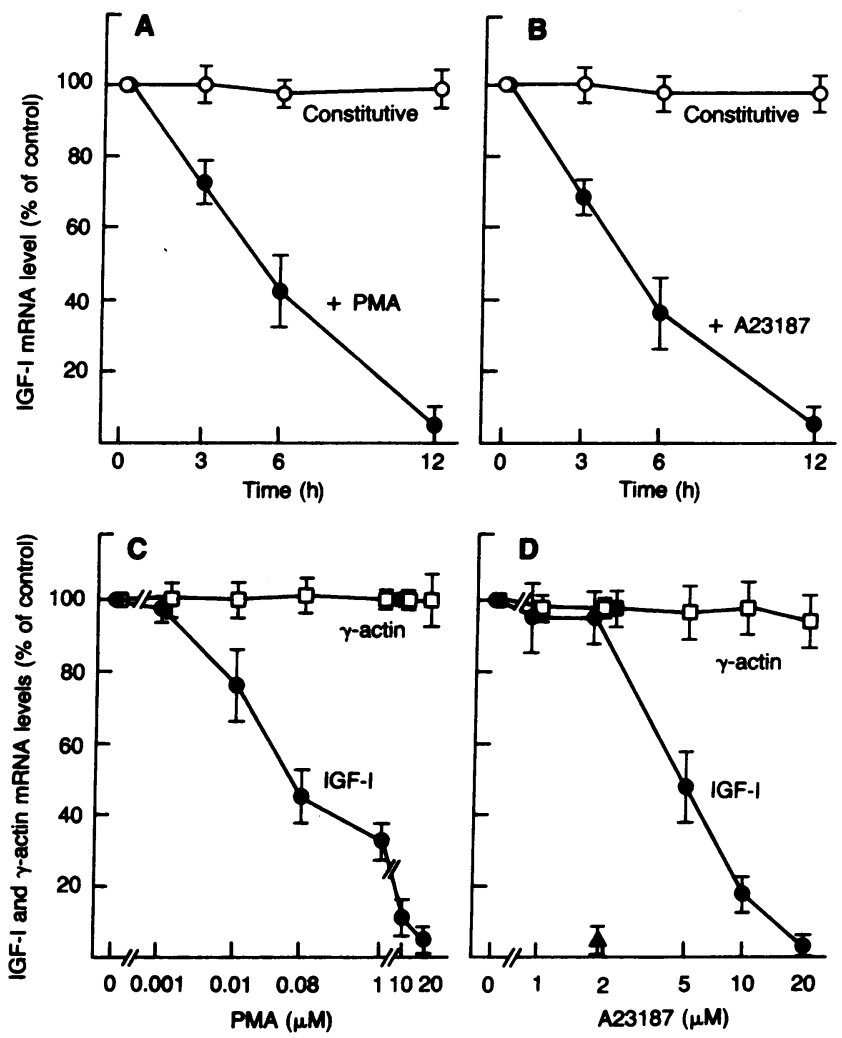

Figure 3. Effect of surface activation on IGF-I mRNA levels in U937 cells. $A$, Time-dependent changes in IGF-I mRNA levels after incubation with PMA ( $80 \mathrm{nM}$ ) compared with constitutive levels (i.e., without activation). $B$, Similar to $A$, but after stimulation with A23187 $(5 \mu \mathrm{M})$ compared with constitutive levels. $C$, IGF-I mRNA levels compared with $\gamma$-actin mRNA levels in U937 cells after incubation for $6 \mathrm{~h}$ with increasing concentrations of PMA (0-20 $\mu \mathrm{M}) . D$, Similar to $C$, but after activation with A23187 $(0-20 \mu \mathrm{M})$. The effect of the combination of PMA (1 nM) + A23187 ( $2 \mu \mathrm{M})$ on IGF-I ( $\Delta)$ and $\gamma$-actin ( $\square$ ) mRNA levels is also indicated. After incubation, total cellular RNA was isolated and the amount of IGF-I mRNA was quantified using a ${ }^{32} \mathrm{P}$-labeled IGF-I cRNA probe and $\gamma$-actin mRNA transcripts quantified with a ${ }^{32} \mathrm{P}$-labeled $\gamma$-actin cDNA probe. For $A$ and $B$, IGF-I mRNA levels were expressed as a percentage of mRNA levels in cells at zero time. For $C$ and $D$, IGF-I and $\gamma$ actin mRNA levels were expressed as a percentage of mRNA levels in cells incubated under identical conditions, but without added stimuli.

involved calmodulin, W-7 (a calmodulin antagonist [36]) completely prevented the A23187-induced reduction of IGF-I mRNA levels (Table I), while W-7 itself did not affect the IGF-I mRNA level of resting cells. Furthermore, $\mathrm{H}-7$ did not prevent the A23187-induced IGF-I mRNA reduction, and W-7 did not prevent the PMA-induced IGF-I mRNA reduction (not shown).

Importance of RNA synthesis and protein synthesis on IGF-I mRNA levels. Active RNA and protein synthesis were important in the control of IGF-I mRNA levels in U937 cells, but in a complex fashion (Figs. 5 and 6). Actinomycin D increased IGF-I mRNA levels in resting cells over 3-6 $\mathrm{h}$ by $\sim 200 \%$ of the initial level but markedly decreased the levels thereafter (Fig. $5 \mathrm{~A}$ ). In contrast, the level of $\gamma$-actin mRNA declined steadily throughout the time interval. While PMA or A23187 stimulation alone reduced IGF-I mRNA levels to

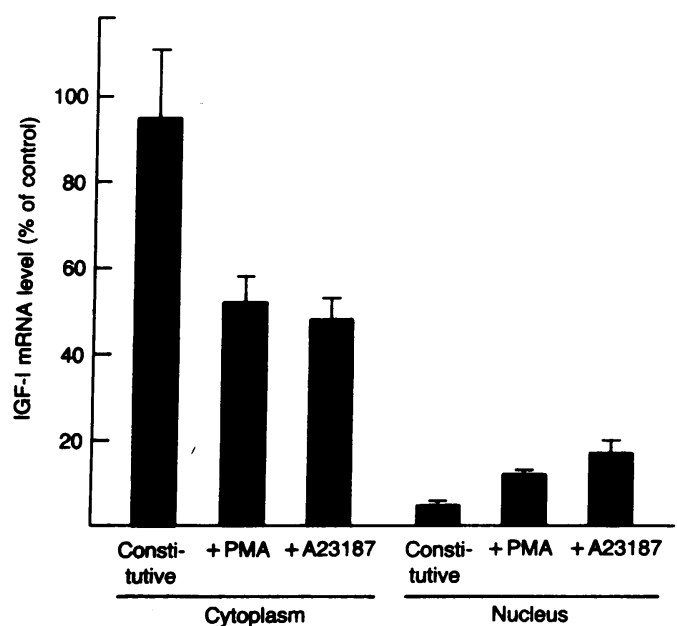

Figure 4. Changes in IGF-I cytoplasmic and nuclear mRNA levels after cell surface stimulation. U937 cells were incubated $\left(6 \mathrm{~h}, 37^{\circ} \mathrm{C}\right)$ with or without stimuli (PMA [80 nM] or A23187 [5 $\mu$ M]). Cytoplasmic and nuclear fractions were obtained and IGF-I mRNA was quantified using a ${ }^{32} \mathrm{P}$-labeled IGF-I cRNA probe. The IGF-I mRNA levels are expressed as a percentage of IGF-I mRNA levels in total cellular RNA from cells incubated under identical conditions except without stimuli. In resting U937 cells $>95 \%$ of the total cellular IGF-I mRNA was present in the cytoplasm.

$\sim 45 \%$ of the control level after $6 \mathrm{~h}$ (Fig. $5 \mathrm{~B}$ ), in the presence of actinomycin D plus PMA or A23187 IGF-I mRNA levels remained markedly increased (Fig. $5 B$ ). In contrast to the variable time-dependent changes in IGF-I mRNA levels after blockage of RNA synthesis, cycloheximide treatment of the cells demonstrated a continuous time-dependent increase in IGF-I mRNA levels. This effect appeared to be relatively specific, since $\gamma$-actin mRNA levels were not changed significantly by cycloheximide during this period (Fig. $6 \mathrm{~A}$ ). In the presence of cycloheximide plus PMA or A23187, IGF-I mRNA levels remained markedly increased, suggesting that active protein synthesis is involved in downregulating IGF-I mRNA levels in resting cells and after surface stimulation (Fig. $6 B)$.

Effect of cell activation on IGF-I protein release. Resting U937 cells constantly released IGF-I at a rate of $\sim 20 \mathrm{pg}$ IGF-I/ $10^{7}$ cells per 15 min (Fig. $7 A$ ). In contrast, both PMA

Table I. Effect of Protein Kinase C Inhibitor and Calmodulin Antagonist on IGF-I mRNA Levels in U937 Cells

\begin{tabular}{cc}
\hline \multicolumn{1}{c}{ Condition } & $\begin{array}{c}\text { IGF-I mRNA level } \\
(\% \text { of control })^{*}\end{array}$ \\
\hline Control & 100 \\
$+100 \mu \mathrm{M} \mathrm{H}-7$ & $100 \pm 6$ \\
$+80 \mathrm{nM}$ PMA & $44 \pm 8$ \\
$+100 \mu \mathrm{M} \mathrm{H}-7,80 \mathrm{nM}$ PMA & $96 \pm 9$ \\
$+25 \mu \mathrm{M}$ W-7 & $97 \pm 3$ \\
$+5 \mu \mathrm{M} \mathrm{A23187}$ & $47 \pm 9$ \\
$+25 \mu \mathrm{M} \mathrm{W}-7,5 \mu \mathrm{M} \mathrm{A23187}$ & $99 \pm 3$
\end{tabular}

* IGF-I mRNA levels expressed as a percentage of levels measured in untreated cells incubated under identical conditions except without stimuli or inhibitors. 

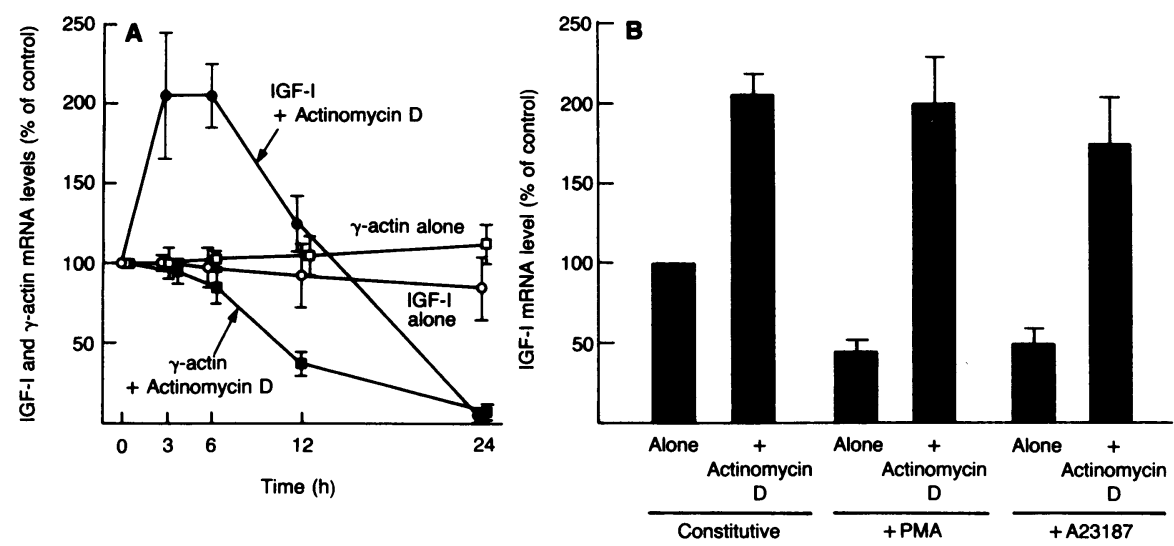

Figure 5. Effect of inhibition of RNA synthesis on IGF-I mRNA levels compared with $\gamma$-actin mRNA levels in resting and stimulated U937 cells. $A$, Cells incubated $\left(0-24 \mathrm{~h}, 37^{\circ} \mathrm{C}\right)$ alone or with actinomycin $\mathrm{D}(10 \mu \mathrm{g} / \mathrm{ml}) . B$, Cells incubated $(6 \mathrm{~h}$ $37^{\circ} \mathrm{C}$ ) with or without stimuli (PMA [80 $\mathrm{nM}]$ or A23187 [5 $\mu \mathrm{M}])$ in the absence or presence of actinomycin $\mathrm{D}(10 \mu \mathrm{g} / \mathrm{ml})$. For $A$ and $B$, after incubation total cellular RNA was isolated, and IGF-I and $\gamma$-actin mRNA were quantified using a ${ }^{32} \mathrm{P}$-labeled IGF-I cRNA probe or a ${ }^{32} \mathrm{P}$-labeled $\gamma$-actin cDNA probe, respectively. For $A$, cellular IGF-I and $\gamma$-actin mRNA levels were expressed as a percentage of mRNA levels in cells at zero time. For $B$, cellular IGF-I mRNA levels were expressed as a percentage of the levels in control cells incubated under identical conditions except without stimuli or actinomycin D. and A23187 caused a very rapid, large increase in the rate of IGF-I release after stimulation, reaching $210 \mathrm{pg}$ IGF-I/ $10^{7}$ cells in the first $15 \mathrm{~min}$. Subsequently, the rate quickly returned to the level of resting cells and decreased gradually thereafter. In the presence of cycloheximide the response to PMA or A23187 at 15 min was unchanged (Fig. $7 \mathrm{~B}$ ), indicating that the marked transient surface stimulation-induced increase in IGF-I release was independent of de novo protein synthesis. In contrast, the early constitutive release of IGF-I and late release of IGF-I (Fig. 7 B) was completely abolished by cycloheximide. To ensure that protein synthesis was effectively inhibited by the amounts of cyclohexamide used, total protein synthesis was estimated by the incorporation of $\left[{ }^{14} \mathrm{C}\right]$ leucine into TCA precipitable radioactivity. The incorporation at $15 \mathrm{~min}$ was $8.3 \times 10^{5} \mathrm{dpm} / 10^{7}$ cells for resting cells, $9.9 \times 10^{5} \mathrm{dpm}$ for PMA-stimulated cells, and $9.4 \times 10^{5} \mathrm{dpm}$ for A23187-stimulated cells, and the incorporation was inhibited by $\geq 95 \%$ in all three conditions in the presence of cycloheximide (not shown). Quantification of the intracellular IGF-I pool in resting U937 cells demonstrated $475 \pm 33$ pg IGF-I $/ 10^{7}$ cells, more than twice the amount released with surface stimulation. To demonstrate that our IGF-I measurements were not hampered by the presence of binding proteins, RIA was performed on both acidified and untreated (neutral $\mathrm{pH}$ ) supernatants or cell sonicates (acidification is known to release IGF-I from binding proteins $[4,5,32])$. There was no difference in measurements made on acidified and neutral supernatants or cell sonicates (acidified $95 \pm 6 \%$ of neutral), suggesting that U937 cell IGF-I is not associated with binding proteins. As a control, acidification of human serum demonstrated a $200 \%$ increase in immunoreactive IGF-I concentrations as noted by others (32).

\section{Discussion}

Mononuclear phagocytes play a central role in normal wound healing and pathologic tissue fibrosis by releasing polypeptide growth factors that modulate mesenchymal cell proliferation in the local milieu $(1-3,8-11)$. Among these mediators is a 20-25 kD product of the IGF-I gene, a single chain polypeptide that stimulates mesenchymal cells late in the $G 1$ phase of
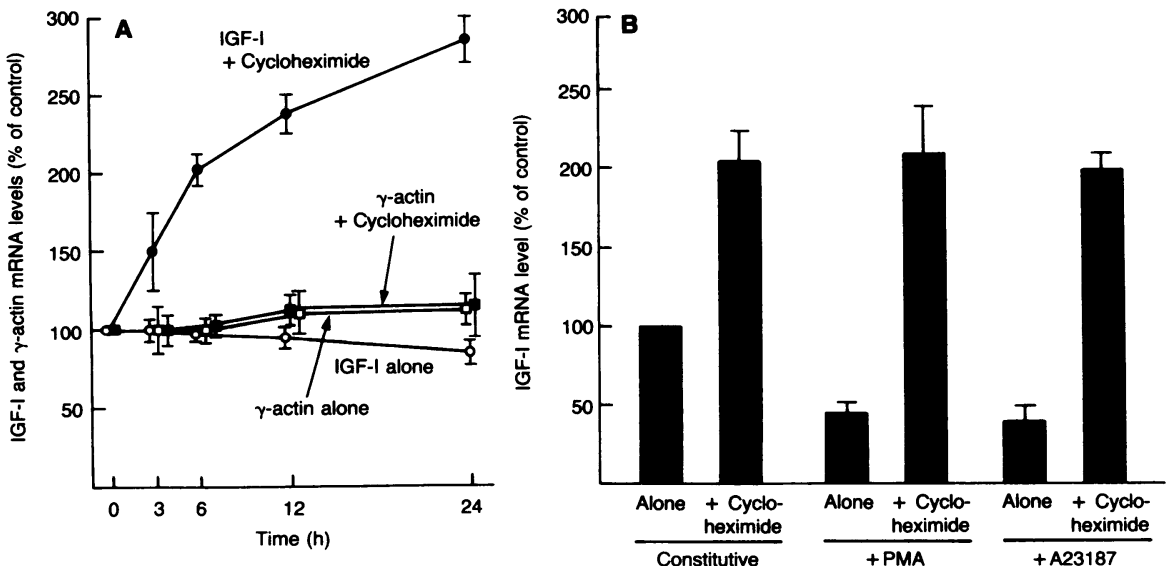

Figure 6. Effect of inhibition of protein synthesis on IGF-I mRNA levels compared with $\gamma$-actin mRNA levels in resting and stimulated U937 cells. $A$, Cells incubated $\left(0-24 \mathrm{~h}, 37^{\circ} \mathrm{C}\right)$ alone or with cycloheximide $(10 \mu \mathrm{g} / \mathrm{ml}) . B$, Cells incubated $(6 \mathrm{~h}$, $37^{\circ} \mathrm{C}$ ) with or without stimuli (PMA [80 $\mathrm{nM}]$ or A23187 [5 $\mu \mathrm{M}])$ in the absence or presence of cycloheximide $(10 \mu \mathrm{g} / \mathrm{ml})$. For $A$ and $B$, after incubation total cellular RNA was isolated and IGF-I and $\gamma$-actin mRNA were quantified using a ${ }^{32} \mathrm{P}$-labeled IGF-I cRNA probe or ${ }^{32} \mathrm{P}$-labeled $\gamma$-actin cDNA probe, respectively. For $A$, cellular IGF-I and $\gamma$-actin mRNA levels were expressed as a percentage of $\mathrm{mRNA}$ levels in cells at zero time. For $B$, IGF-I mRNA levels were expressed as a percentage of the levels in control cells incubated under identical conditions except without stimuli or cycloheximide. 

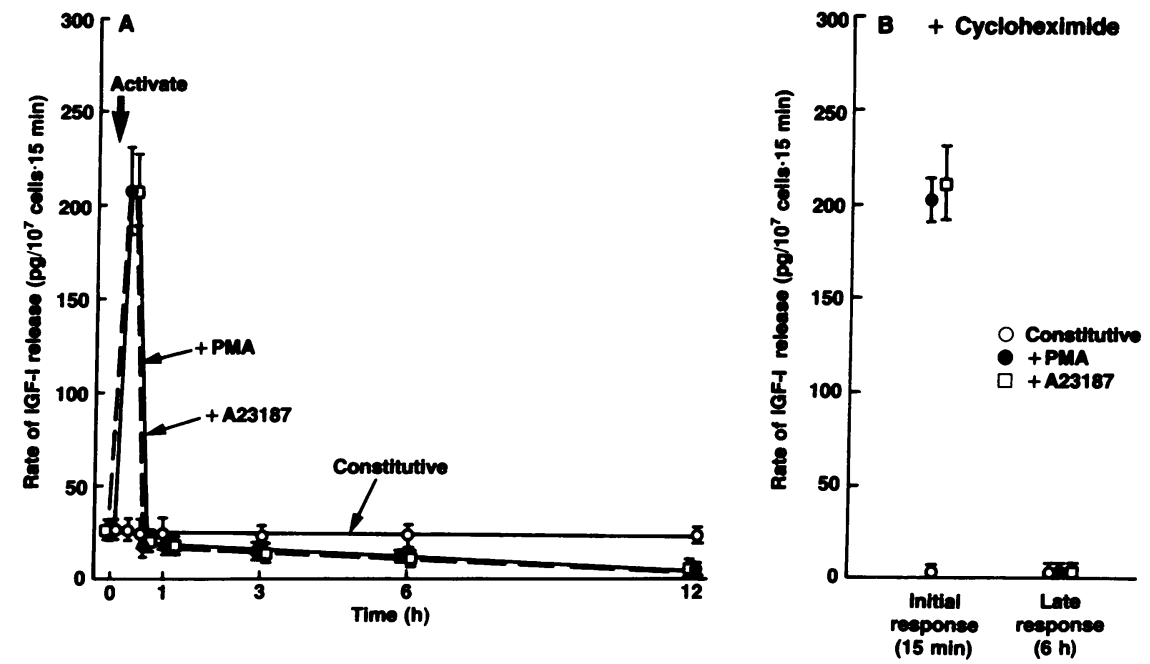

Figure 7. Release of IGF-I from U937 cells after surface activation. $A$, Cells were incubated $\left(0-12 \mathrm{~h}, 37^{\circ} \mathrm{C}\right)$ with or without stimuli (PMA [80 nM] or A23187 [5 $\mu \mathrm{M}$ ]). After the incubation, IGF-I was quantitated in the extracellular medium using an IGF-I-specific RIA. IGF-I release is expressed as the rate of IGF-I released (pg/10 $10^{7}$ cells per $\left.15 \mathrm{~min}\right)$. Shown are data for constitutive release (o), and release after PMA (•) or A23187 () surface activation. Arrow, time of cell activation. $B$, Effect of inhibition of protein synthesis on the initial $(15 \mathrm{~min})$ and late $(6 \mathrm{~h})$ IGF-I release by stimulated U937 cells. Cells were incubated in the presence of cycloheximide $(10 \mathrm{mg} / \mathrm{ml})$ alone (O) or with PMA (•) or A23187 (), and IGF-I was quantified in supernatants as indicated in $A$. the cell cycle to proliferate (4-7). Using U937 cells, a human macrophage-like cell line that expresses IGF-I mRNA transcripts in a fashion similar to that of human alveolar macrophages, the present study evaluates the modulation of expression of this gene. At rest, U937 cells transcribe the IGF-I gene, express IGF-I mRNA, and release IGF-I at a low level. When activated by the surface stimuli PMA or calcium ionophore A 12387, the rate of IGF-I gene transcription is increased and the small increase in nuclear IGF-I mRNA levels reflects this. However, in the cytoplasm IGF-I mRNA levels markedly decrease in a time-dependent fashion by mechanisms involving protein kinase $\mathrm{C}$ (for PMA surface activation) and calmodulin (for the calcium ionophore modulation), and active protein synthesis. Despite this striking fall in cytoplasmic IGF-I mRNA levels, surface activation causes a rapid release of IGF-I from the cell, a process that occurs in the presence of cycloheximide, suggesting these cells have preformed stored IGF-I that can be released immediately as the need arises.

Regulation of IGF-I gene transcription. The surface stimuli PMA and calcium ionophore increased IGF-I gene transcription four- to fivefold over the resting level. Consistent with the upregulation of IGF-I gene transcription in this macrophagelike cell line, the constitutive IGF-I gene transcription in liver cells of growth hormone-deficient mice (37) can be modulated by cell surface signals, in this case by growth hormone. Interestingly, the upregulation of IGF-I gene transcription in U937 cells by PMA or calcium ionophore seems to require active protein synthesis in a fashion similar to the modulation of the upregulation of the c-myc oncogene by nerve growth factor in the pheochromocytoma cell line PC12 (38).

Regulation of IGF-I mRNA transcript levels. General inhibition of RNA synthesis induced a transient increase in the resting IGF-I mRNA levels, and then IGF-I mRNA levels fell to zero, probably due to the degradation of RNA after inhibition of RNA transcription. Thus, constitutively, it appears that IGF-I transcript levels are regulated at the level of transcription. The unexpected, marked decline in IGF-I mRNA levels after surface activation of U937 cells by PMA or A23187 is opposite the change in IGF-I mRNA levels in liver cells by growth hormone. In this regard, the studies in growth hormone-deficient mice by Mathews et al. (37) have demonstrated that IGF-I mRNA levels paralleled the rate of tran- scription of the gene (i.e., when growth hormone was given, both transcription and mRNA levels increased significantly).

Evaluation of the possible pathways for transduction of the surface stimuli that result in the reduction of IGF-I mRNA levels suggested that PMA activation works, at least in part, through protein kinase $C$, while calcium ionophore activation works through calmodulin-type molecule(s). In addition, the pathways used by these two stimuli probably share a common mechanism(s) in the reduction of cytoplasmic IGF-I transcript numbers in U937 cells, since low levels of PMA and the calcium ionophore appeared to work synergistically and this mechanism seems to be dependent on active protein synthesis. Furthermore, in the short term after surface activation, general inhibition of transcription caused a marked increase in IGF-I mRNA levels and blocked the expected reduction of IGF-I mRNA levels by surface stimuli. Thus, regulation of cytoplasmic IGF-I mRNA levels after surface activation involves cytoplasmic signal transduction pathways such as protein kinase $\mathrm{C}$ and calmodulin, active protein synthesis, active IGF-I gene transcription, and probably transcription of a gene(s) other than IGF-I.

The actual mechanism(s) by which the IGF-I mRNA levels are selectively decreased in U937 cells is not known, but one possibility is the involvement of an AU-rich sequence in the $3^{\prime}$ untranslated region of the IGF-I mRNA in a fashion proposed for cytokines such as granulocyte-macrophage colony-stimulating factor, tumor necrosis factor, and protooncogenes like c-fos (39-42). These genes, the transcripts of which are expressed transiently, contain repeats of the conserved AU-rich sequences (AUUUA) in the $3^{\prime}$ untranslated region of their RNA $(39,40)$, while genes known to express relatively stable transcripts (e.g., glyceraldehyde 3-phosphate dehydrogenase), do not have this $3^{\prime}$ AU-rich sequence $(43,44)$, suggesting that such sequences are recognition sites for mRNA processing mechanisms that degrade specific transcripts. Interestingly, IGF-I mRNA transcripts contain an identical AU-rich sequence in the $3^{\prime}$ untranslated regions of exons IV and V, respectively (14-16). However, as compelling as this hypothesis may be, it must be recognized that $\gamma$-actin also contains the AU-rich sequence in $3^{\prime}$ untranslated region (45), even though $\gamma$-actin mRNA levels in the U937 cells remained constant under the identical conditions in which IGF-I mRNA levels 
declined. Thus, the changes in IGF-I mRNA levels cannot be explained simply by the presence of the AU-rich sequence which may be necessary but not sufficient. Alternatively, IGF-I mRNA levels might be regulated by some labile protein(s), such as a sequence-specific RNAse (41), which presumably requires active RNA and protein synthesis and could be induced by PMA- or A23187 stimulation.

Regulation of IGF-I synthesis and release. U937 cells constitutively release IGF-I, but this release of IGF-I was inhibited by cycloheximide, suggesting that these cells actively synthesize and release this polypeptide. In contrast, the marked upregulation of IGF-I release immediately after surface stimulation was rapid, transient, and independent of protein synthesis. Finally, correlation of the parallel reductions in IGF-I mRNA levels and the rate of IGF-I secretion 6-12 $\mathrm{h}$ after cell surface stimulation suggest that the rate of IGF-I release from stimulated cells at later times (after the initial rapid release) is modulated by the levels of IGF-I mRNA in the cells. Together, these observations suggest that the IGF-I release from resting cells is derived from newly synthesized protein, whereas surface stimulation caused IGF-I release from a preformed cellular storage pool.

The concept that mononuclear phagocytes might store polypeptides like IGF-I is relatively novel; the only clear example of such a process is IL-1, where cytoplasmic storage and binding to the plasma membrane has been clearly documented (46-48). However, unlike IGF-I, IL-1 release after surface activation of mononuclear phagocytes requires active protein synthesis (47), although it is not clear if some IL-1 synthesis occurs or the synthesis of other proteins is required for IL-1 release. Interestingly, Rotwein et al. (20) have pointed out that all known translation products of IGF-I mRNA transcripts have an atypical, large (48 amino acid) $\mathbf{N H}_{2}$-terminal signal peptide. Analysis of the signal peptide sequence showed two general domains; a 19 residue portion at the $\mathrm{COOH}$-terminal region that is typical for a signal peptide and an $\mathrm{NH}_{2}$-terminal region with many cysteine residues. The role of this cysteinerich region is unknown, but it is tempting to speculate that it may be involved in the intracellular storage of IGF-I and/or its ability to be rapidly released after surface activation.

Independent of the mechanism controlling the process, the fact that U937 cells can rapidly release presynthesized IGF-I is consistent with the role of mononuclear phagocytes in wound healing and tissue fibrosis. Thus, like the platelet that carries preformed growth factors such as platelet-derived growth factor, the mononuclear phagocyte may be primed to augment mesenchymal cell growth.

\section{Acknowledgments}

We thank P. Rotwein, Washington University, for providing the human IGF-IA cDNA; P. Gunning and L. Kedes, Stanford University, for providing $\mathrm{pHF} \gamma \mathrm{A}-1 ; \mathrm{T}$. Nukiwa for preparing the riboprobe template pPB107 derived from the IGF-IA CDNA; Z. Borok for helping with the IGF-I RIA; and L. Sichert for editorial assistance.

\section{References}

1. Leibovich, S. J., and R. Ross. 1975. The role of the macrophage in wound repair: a study with hydrocortisone and antimacrophage serum. Am. J. Pathol. 78:71-100.

2. Agelli, M., and S. M. Wahl. 1986. Cytokines and fibrosis. Clin. Exp. Rheumatol. 4:379-388.
3. Nathan, C. F. 1987. Secretory products of macrophages. J. Clin. Invest. 79:319-326.

4. Van Wyk, J. J. 1985. The somatomedins: biological actions and physiologic control mechanisms. In Hormonal Proteins and Peptides. Vol. XII. C. H. Li, editor. Academic Press, Inc., New York. 81-125.

5. Nissley, S. P., and M. M. Rechler. 1985. Insulin-like growth factors: biosynthesis, receptors, and carrier proteins. In Hormonal Proteins and Peptides. Vol. XII. C. H. Li, editor. Academic Press, Inc., New York. 127-203.

6. Pledger, W. J., C. D. Stiles, H. N. Antoniades, and C. D. Scher. 1977. Induction of DNA synthesis in BALB/c 3T3 cells by serum components: reevaluation of the commitment process. Proc. Natl. Acad. Sci. USA. 74:4481-4485.

7. Pledger, W. J., C. D. Stiles, H. N. Antoniades, and C. D. Scher. 1978. An ordered sequence of events is required before BALB/c-3T3 cells become committed to DNA synthesis. Proc. Natl. Acad. Sci. USA. 75:2839-2843.

8. Rom, W. N., P. Basset, G. A. Fells, T. Nukiwa, B. C. Trapnell, and R. G. Crystal. 1988. Alveolar macrophages release an insulin-like growth factor I-type molecule. J. Clin. Invest. 82:1685-1693.

9. Crystal, R. G., P. B. Bitterman, S. I. Rennard, A. J. Hance, and B. A. Keogh. 1984. Interstitial lung diseases of unknown cause: disorders characterized by chronic inflammation of the lower respiratory tract. N. Engl. J. Med. 310:154-166, 235-244.

10. Bitterman, P. B., S. Adelberg, and R. G. Crystal. 1983. Mechanisms of pulmonary fibrosis: spontaneous release of the alveolar macrophage-derived growth factor in the interstitial lung disorders. J. Clin. Invest. 72:1801-1813.

11. Rom, W. N., P. B. Bitterman, S. I. Rennard, A. Cantin, and R. G. Crystal. 1987. Characterization of the lower respiratory tract inflammation of nonsmoking individuals with interstitial lung disease associated with chronic inhalation of inorganic dusts. Am. Rev. Respir. Dis. 136:1429-1434.

12. Brissenden, J. E., A. Ullrich, and U. Francke. 1984. Human chromosomal mapping of genes for insulin-like growth factors I and II and epidermal growth factor. Nature (Lond.). 310:781-784.

13. Tricoll, J. V., L. B. Rall, J. Scott, G. I. Bell, and T. B. Shows. 1984. Localization of insulin-like growth factor genes to human chromosomes 11 and 12. Nature (Lond.). 310:784-786.

14. Rotwein, P., K. M. Pollock, D. K. Didier, and G. G. Krivi. 1986. Organization and sequence of the human insulin-like growth factor I gene. J. Biol. Chem. 261:4828-4832.

15. Jansen, M., F. M. A. van Schaik, A. T. Ricker, B. Bullock, D. E. Woods, K. H. Gabbay, A. L. Nussbaum, J. S. Sussenbach, and J. L. Van den Brande. 1983. Sequence of cDNA encoding human insulinlike growth factor I precursor. Nature (Lond.). 306:609-611.

16. Rotwein, P. 1986. Two insulin-like growth factor I messenger RNAs are expressed in human liver. Proc. Natl. Acad. Sci. USA. 83:77-81.

17. Trapnell, B. C., I. Nagaoka, W. Rom, Z. Borok, and R. G. Crystal. 1989. Modulation of insulin-like growth factor-I gene expression in human mononuclear phagocytes. J. Cell Biol. 107:702A. (Abstr.)

18. Clemmons, D. R., and D. S. Shaw. 1986. Purification and biologic properties of fibroblast somatomedin. J. Biol. Chem. 261:10293-10298.

19. Smith, E. P., M. E. Svoboda, J. J. Van Wyk, A. L. Kierszenbaum, and L. L. Tres. 1987. Partial characterization of a somatomedin-like peptide from the medium of cultured rat Sertoli cells. Endocrinology. 120:186-193.

20. Rotwein, P., R. J. Folz, and J. I. Gordon. 1987. Biosynthesis of human insulin-like growth factor I (IGF-I): the primary translation product of IGF-I mRNA contains an unusual 48-amino acid signal peptide. J. Biol. Chem. 262:11807-11812.

21. Rinderknecht, E., and R. E. Humbel. 1978. The amino acid sequence of human insulin-like growth factor $I$ and its structural homology with proinsulin. J. Biol. Chem. 253:2769-2776.

22. Sundstrom, C., and K. Nilsson. 1976. Establishment and char- 
acterization of a human histiocytic lymphoma cell line (U-937). Int. J. Cancer. 17:565-577.

23. Harris, P., and P. Ralph. 1985. Human leukemic models of myelomonocytic development: a review of the HL-60 and U937 cell lines. J. Leukocyte Biol. 37:407-422.

24. Saltini, C., A. J. Hance, V. J. Ferrans, F. Basset, P. B. Bitterman, and R. G. Crystal. 1984. Accurate quantification of cells recovered by bronchoalveolar lavage. Am. Rev. Respir. Dis. 130:650-658.

25. Chirgwin, J. M., A. E. Przybyla, R. J. MacDonald, and W. J. Rutter. 1979. Isolation of biologically active ribonucleic acid from sources enriched in ribonuclease. Biochemistry. 18:5294-5299.

26. Feinberg, A. P., and B. Vogelstein. 1983. A technique for radiolabeling DNA restriction endonuclease fragments to high specific activity. Anal. Biochem. 132:6-13.

27. Zinn, K., D. DiMaio, and T. Maniatis. 1983. Identification of two distinct regulatory regions adjacent to the human $\beta$-interferon gene. Cell. 34:865-879.

28. Groudine, M., M. Peretz, and H. Weintraub. 1981. Transcriptional regulation of hemoglobin switching in chicken embryos. $\mathrm{Mol}$. Cell. Biol. 1:281-288.

29. Mitchell, R. L., C. Henning-Chubb, E. Huberman, and I. M. Verma. 1986. c-fos expression is neither sufficient nor obligatory for differentiation of monomyelocytes to macrophages. Cell. 45:497-504.

30. Gunning, P., P. Ponte, H. Okayama, J. Engel, H. Blau, and L. Kedes. 1983. Isolation and characterization of full-length cDNA clones for human $\alpha-, \beta$-, and $\gamma$-actin mRNAs: skeletal but not cytoplasmic actins have an amino-terminal cysteine that is subsequently removed. Mol. Cell. Biol. 3:787-795.

31. Baumbach, L. L., G. S. Stein, and J. L. Stein. 1987. Regulation of human histone gene expression: transcriptional and posttranscriptional control in the coupling of histone messenger RNA stability with DNA replication. Biochemistry. 26:6178-6187.

32. Chatelain, P. G., J. J. Van Wyck, K. C. Copeland, S. L. Blethen, and L. E. Underwood. Effect of in vitro action of serum proteases or exposure to acid on measurable immunoreactive somatomedin-c in serum. J. Clin. Endocrinol. Metab. 56:376-383.

33. Nishizuka, Y. 1984. The role of protein kinase $C$ in cell surface signal tranduction and tumour promotion. Nature (Lond.). 308:693698.

34. Ashendel, C. L. 1985. The phorbol ester receptor: a phospholipid-regulated protein kinase. Biochim. Biophys. Acta. 822:219-242.

35. Hidaka, H., M. Inagaki, S. Kawamoto, and Y. Sasaki. 1984. Isoquinolinesulfonamides, novel and potent inhibitors of cyclic nucleotide dependent protein kinase and protein kinase C. Biochemistry. 23:5036-5041.
36. Tanaka, T., and H. Hidaka. 1980. Hydrophobic regions function in calmodulin-enzyme(s) interactions. J. Biol. Chem. 255:1107811080.

37. Mathews, L. S., G. Norstedt, and R. D. Palmiter. 1986. Regulation of insulin-like growth factor I gene expression by growth hormone. Proc. Natl. Acad. Sci. USA. 83:9343-9347.

38. Greenberg, M. E., A. L. Hermanowski, and E. B. Ziff. 1986. Effect of protein synthesis inhibitors on growth factor activation of c-fos, c-myc, and actin gene transcription. Mol. Cell. Biol. 6:10501057.

39. Caput, D., B. Beutler, K. Hartog, R. Thayer, S. Brown-Shimer, and $A$. Cerami. 1986. Identification of a common nucleotide sequence in the 3'-untranslated region of mRNA molecules specifying inflammatory mediators. Proc. Natl. Acad. Sci. USA. 83:1670-1674.

40. Shaw, G., and R. Kamen. 1986. A conserved AU sequence from the $3^{\prime}$ untranslated region of GM-CSF mRNA mediates selective mRNA degradation. Cell. 46:659-667.

41. Brawerman, G. 1987. Determinants of messenger RNA stability. Cell. 48:5-6.

42. Kozak, M. 1988. A profusion of controls. J. Cell Biol. 107:1-7.

43. Hanauer, A., and J. L. Mandel. 1984. The glyceraldehyde 3 phosphate dehydrogenase gene family: structure of a human cDNA and of an $\mathrm{X}$ chromosome linked psuedogene: amazing complexity of the gene family in mouse. EMBO (Eur. Mol. Biol. Organ.) J. 3:26272633.

44. Blanchard, J.-M., M. Piechaczyk, C. Dani, J.-C. Chambard, A. Franchi, J. Pouyssegur, and P. Jeanteur. 1985. c-myc gene is transcribed at high rate in $\mathrm{G}_{0}$-arrested fibroblasts and is posttranslationally regulated in response to growth factors. Nature (Lond.). 317:443-445.

45. Erba, H. P., R. Eddy, T. Shows, L. Kedes, and P. Gunning. 1988. Structure, chromosome location, and expression of the human $\gamma$-actin gene: differential evolution, location, and expression of the cytoskeletal $\beta$ - and $\gamma$-actin genes. Mol. Cell. Biol. 8:1775-1789.

46. Kurt-Jones, E. A., D. I. Beller, S. B. Mizel, and E. R. Unanue. 1985. Identification of a membrane-associated interleukin 1 in macrophages. Proc. Natl. Acad. Sci. USA. 82:1204-1208.

47. Matsushima, K., M. Taguchi, E. J. Kovacs, H. A. Young, and J. J. Oppenheim. 1986. Intracellular localization of human monocyte associated interleukin 1 (IL 1) activity and release of biologically active IL 1 from monocytes by trypsin and plasmin. J. Immunol. 136:28832891.

48. Bakouche, O., D. C. Brown, and L. B. Lachman. 1987. Subcellular localization of human monocyte interleukin 1: evidence for an inactive precursor molecule and a possible mechanism for IL 1 release. J. Immunol. 138:4249-4255. 